\title{
Dietary protein requirement of Pacific white shrimp Litopenaeus vannamei in three different growth stages
}

\author{
Chorong Lee and Kyeong-Jun Lee ${ }^{*}$ (D)
}

\begin{abstract}
A study of three feeding trials was conducted to investigate the dietary protein requirements of Pacific white shrimp (Litopenaeus vannamei) at three different growth stages. Six experimental diets were formulated to include increasing protein levels of 25, 30, 35, 40, 45, and 50\% (designated as P25, P30, P35, P40, P45, and P50, respectively) for three feeding trials. The three feeding trials were conducted in different-sized shrimp at $0.65 \mathrm{~g}$ (trial 1), $4.80 \mathrm{~g}$ (trial 2), and $10.5 \mathrm{~g}$ (trial 3). Triplicate groups of shrimp were fed one of the experimental diets for 36, 42, and 48 days in trials 1, 2, and 3, respectively. In trial 1, the growth performance was not affected by the dietary protein levels. However, protein efficiency ratio was significantly higher in P30 diet compared to P40, P45, and P50 diets. In trial 2, growth rate was significantly higher in P35 diet than in P25 diet. In trial 3, the lowest growth performance was obtained in P25 diet which significantly differed from that of other experimental diets. Broken line analysis of growth data indicates that the optimal dietary level of crude protein is $34.5,35.6$, and $32.2 \%$ for small-, medium-, and large-sized (juvenile, sub-adult, and adult stages) Pacific white shrimp, respectively.
\end{abstract}

Keywords: Protein requirement, Semi-purified diet, Growth performance, Litopenaeus vannamei

\section{Background}

The Pacific white shrimp, Litopenaeus vannamei (Boone, 1931), one of the most important farming shrimp species in the last decade, occupies a vital position in aquaculture industry. However, basic nutritional data such as protein requirement, $\mathrm{P} / \mathrm{E}$ ratio, vitamins, and minerals in diets for the shrimp have not been fully established. The nutritional study in shrimp is generally complicated by the difficulties associated with making water-stable experimental diet. Crustaceans including shrimp shred their food particles prior to ingestion, which leads to rapid leaching and thereby makes their food consumption measurements very difficult Wilson 2002.

Cultured shrimp is supposed to get essential amino acids through the feeds because they cannot synthesize all the amino acids (National Research Council 2011). A minimum dietary protein level is required to supply adequate amino acids for normal maintenance of metabolism and physiology in aquatic animals. Generally,

* Correspondence: kjlee@jejunu.ac.kr

Department of Marine Life Sciences, Jeju National University, Jeju 63243, South Korea low levels of dietary protein lead to rapid growth reduction and weight loss because animals withdraw the necessary protein from their tissues to maintain vital physiological functions. On the other hand, high levels of dietary protein can lead an increment of feed costs and nitrogen excretion into the water because animals only use portions of protein for their body building block and the remaining portion is converted into energy which can be easily obtained from cheap carbohydrates or lipids (Zhou et al. 2007). The dietary protein contents can significantly affect the water quality via nitrogen excretion. In the case of shrimp culture system, most of nitrogen input into the water column is generated by feeds and is not converted to shrimp tissues.

The optimal dietary protein requirement of L. vannamei has been reported from 20 to $45 \%$ depending on the shrimp size, water conditions, and dietary characteristics such as, protein quality, energy content, and palatability (Velasco et al. 2000; Martinez-Cordova et al. 2003; Perez-Velazquez et al. 2007; Venero et al. 2008; Jatobá et al. 2014; Shahkar et al. 2014; Sui et al. 2015; Yun et al. 2015; Yun et al. 2016). Most of the previous studies have 
used practical diets for the requirement of protein in shrimp. This study, therefore, was conducted to determine the optimal protein requirements of Pacific white shrimp in three different growth stages following exposure to a semi-purified diet.

\section{Materials and methods}

\section{Experimental diets and design}

Formulation and proximate compositions of the experimental diets for trials 1,2 , and 3 are shown in Table 1. Six semi-purified diets were formulated to contain crude protein levels of $25,30,35,40,45$, and $50 \%$ (designated as P25, P30, P35, P40, P45, and P50, respectively) by increasing casein and gelatin at the expense of starch. All dry materials were thoroughly mixed (NVM-16, Gyeonggido, South Korea) and pelleted through a pellet machine (SP-50; Gumgang Engineering, Daegu, South Korea) after addition of fish oil and distilled water. The pelleted diets were dried at $25{ }^{\circ} \mathrm{C}$ for $24 \mathrm{~h}$, crushed into desirable particle sizes, and stored at $-24{ }^{\circ} \mathrm{C}$ until used.

Table 1 Dietary formulation and proximate composition of the six experimental diets for $L$. vannamei (\% dry matter). All three experimental (trial 1,2, and 3) diets were produced using the same diet formulation

\begin{tabular}{|c|c|c|c|c|c|c|}
\hline \multirow[t]{2}{*}{ Ingredients } & \multicolumn{6}{|c|}{ Experimental diets } \\
\hline & P25 & P30 & P35 & P40 & P45 & P50 \\
\hline Brown fish meal $^{1}$ & 18.0 & 18.0 & 18.0 & 18.0 & 18.0 & 18.0 \\
\hline Gelatin $^{2}$ & 0.50 & 1.50 & 2.50 & 3.50 & 4.50 & 5.50 \\
\hline Casein $^{3}$ & 2.00 & 6.00 & 10.0 & 14.0 & 18.0 & 22.0 \\
\hline Soybean meal & 4.00 & 4.00 & 4.00 & 4.00 & 4.00 & 4.00 \\
\hline Squid liver meal & 5.00 & 5.00 & 5.00 & 5.00 & 5.00 & 5.00 \\
\hline Wheat flour & 34.5 & 34.5 & 34.5 & 34.5 & 34.5 & 34.5 \\
\hline Starch & 30.0 & 25.0 & 20.0 & 15.0 & 10.0 & 5.00 \\
\hline Fish oil & 2.00 & 2.00 & 2.00 & 2.00 & 2.00 & 2.00 \\
\hline $\begin{array}{l}\text { Vitamin/mineral } \\
\text { premix }^{4}\end{array}$ & 2.00 & 2.00 & 2.00 & 2.00 & 2.00 & 2.00 \\
\hline Choline chloride & 1.00 & 1.00 & 1.00 & 1.00 & 1.00 & 1.00 \\
\hline Lecithin & 1.00 & 1.00 & 1.00 & 1.00 & 1.00 & 1.00 \\
\hline \multicolumn{7}{|c|}{ Chemical composition (\% dry matter) } \\
\hline Dry matter & 89.0 & 88.8 & 88.4 & 88.9 & 89.0 & 88.6 \\
\hline Crude protein & 25.9 & 30.4 & 35.8 & 40.2 & 45.0 & 50.1 \\
\hline Crude lipid & 8.12 & 8.09 & 8.18 & 8.17 & 8.27 & 8.23 \\
\hline Crude ash & 5.19 & 5.13 & 5.15 & 5.28 & 5.14 & 5.33 \\
\hline
\end{tabular}

${ }^{1}$ Suhyup Feed Co. Ltd., South Korea (crude protein: 73.1\%, crude lipid: 6.60\%) ${ }^{2}$ Sigma Chemicals, Gelatin

${ }^{3}$ Casein was purchased from USB Co. Ltd., Cleveland, OH, USA

${ }^{4}$ Vitamin/mineral premix ( $\mathrm{g} \mathrm{kg}^{-1}$ of mixture): retinol, 3.0; cholecalciferol, 1.0; ascorbic acid, 20.0; tocopherol, 20.0; menadione, 2.0; thiamine, 4.0; riboflavin, 6.0; pyridoxine, 5.0; cobalamin, 6.0; inositol, 54.0; panththenic acid, 12.0; biotin, 0.2; niacin amide, 40.0; folic acid, 2.0; Ferriccitrate, 10.0; $\mathrm{Cu}, 1.0 ; \mathrm{Zn}, 30 ; \mathrm{Mn}, 2.0$; Co, 10; I, 1.0; K, 6.0; Se, 0.01

\section{Shrimp and feeding trials}

The three feeding trials were conducted in an indoor shrimp culture facility at the Institute of Marine Sciences of Jeju National University (Jeju, South Korea). Three different size groups of L. vannamei were obtained from NeoEnBiz shrimp farm (Dangjin, South Korea) and were acclimated for 2 weeks each during which the shrimp were fed a proper commercial diet (SAJO DongA One, Seoul, South Korea).

In the first feeding trial (trial 1, $0.65 \mathrm{~g}$ size shrimp), the shrimp were randomly distributed into 18 acryl aquaria of $92 \mathrm{~L}$ capacity at a density of 18 shrimp per aquarium with aeration to maintain enough dissolved oxygen. Triplicate groups of shrimp were hand-fed with one of the diets four times a day at 08:30, 13:00, 17:30, and $20: 00 \mathrm{~h}$ for 36 days. The daily feeding rates were slowly reduced from 15 to $6 \%$ of wet body weight during 36 days of the feeding trial.

In the second feeding trial (trial 2, $4.80 \mathrm{~g}$ size shrimp), the shrimp were randomly distributed into 18 acryl aquaria of $92 \mathrm{~L}$ capacity at a density of 12 shrimp per aquarium with enough aeration. The feeding protocol was the same to the trial 1 , but the feeding rate was slightly reduced from 10 to $4 \%$ of biomass during 42 days of the feeding trial.

In the third feeding trial (trial 3, $10.5 \mathrm{~g}$ size shrimp), the shrimp were randomly stocked into 18 acryl aquaria of 216 L capacity at a density of 11 shrimp per aquarium with enough aeration. The feeding protocol was the same to the trial 1 , but the feeding rate was $5 \%$ of the biomass during 48 days of the feeding trial.

Three feeding trials were conducted in the same way except for the duration, shrimp size, and respective feeding rates. The culture water was changed every 3 days, and the aquaria were cleaned with a sponge to prevent the growth of microflora. Fluorescent lighting was maintained for $12 \mathrm{~h}$ light/dark cycle. The water temperature was $28 \pm 2{ }^{\circ} \mathrm{C}$, $\mathrm{pH}$ was $7.5 \pm 0.2$, salinity was $30 \mathrm{~g} \mathrm{~L}^{-1}$, and dissolved oxygen was above $7.0 \mathrm{mg} \mathrm{L}^{-1}$. Total ammonia nitrogen and nitrite were kept $<0.1$ and $0.005 \mathrm{mg} \mathrm{L}^{-1}$, respectively, during the three feeding trials. Shrimp growth was measured every 2 weeks. Feeding was stopped $18 \mathrm{~h}$ prior to weighing to minimize handling stress on the shrimp.

\section{Sample collection and analyses}

At the end of each feeding trial, all the shrimp in each tank were counted and individually weighed for calculation of weight gain (WG), daily body increase (DBI), feed conversion ratio (FCR), protein efficiency ratio (PER), and survival. After weighing, three medium sizes of shrimp were selected from each tank (nine shrimp per dietary treatment) for whole-body analysis in trials 1 and 3 . Analyses of moisture and ash contents of the experimental 
diets and whole-body samples were performed by the standard procedures (AOAC 2005). Crude protein was measured by using an automatic Kjeltec Analyzer Unit 2300 (Foss Tecator, Höganäs, Sweden), and crude lipid was analyzed by Folch et al. (1957).

\section{Statistical analysis}

All diets were assigned by a completely randomized design. Data were analyzed one-way analysis of variance (ANOVA) in SPSS version 18.0 (SPSS Inc., Chicago, IL, USA). When ANOVA identified differences among groups, the difference in means was compared with Duncan's multiple range tests. Statistical significance was determined at $P<0.05$. Weight gain results were fitted to broken line models for the estimation of optimal dietary protein level (Fig. 1). Data are presented as mean \pm SD. Percentage data were arcsine transformed before analysis.

\section{Results}

The results of growth performance, feed utilization, and survival are shown in Table 2 . The average survival was $86.9,85.2$, and $86.9 \%$ for trials 1,2 , and 3 , respectively. In trial 1 , the growth performance was not affected by the dietary protein levels. However, PER was significantly higher in shrimp fed P30 diet compared to those fed P40, P45, and P50 diets. In trial 2, significantly higher growth rate was observed in shrimp fed P35 diet compared to shrimp fed P25 diet. FCR was significantly lower in shrimp fed P35 and P40 diets than that in shrimp exposed to P25 diet. Shrimp exposed to P25, P30, and P35 diets showed significantly higher PER compared to those fed P45 and P50 diets. In trial 3, P25 diet resulted in significantly lower growth rate than other experimental diets. FCR was significantly higher in shrimp fed P25 diet than other experimental diets. PER was significantly higher in shrimp fed P30 diet compared to that of shrimp fed P25, P40, P45, and P50 diets.

As shown in Table 3, significantly higher moisture content was observed in P25 group than in other groups in trial 1. In trial 3, moisture was significantly higher in P25 and P50 than in P30, P40, and P45 groups. Whole-body protein was significantly lower in P25 group than that in other groups.

Broken line analysis of growth data indicates that the optimal levels of crude protein would be 34.5, 35.6, and $32.2 \%$ in diets for small, medium, and large (juvenile, sub-adult, and adult stages) shrimp, respectively.

\section{Discussion}

Growth and feed utilization of aquatic animals fed purified diets are normally lower than those of the animals exposed to practical diets (Kim et al. 1991). Nonetheless, the use of purified diets is inevitable for the study of nutrient requirements. In the present study, fish meal as an

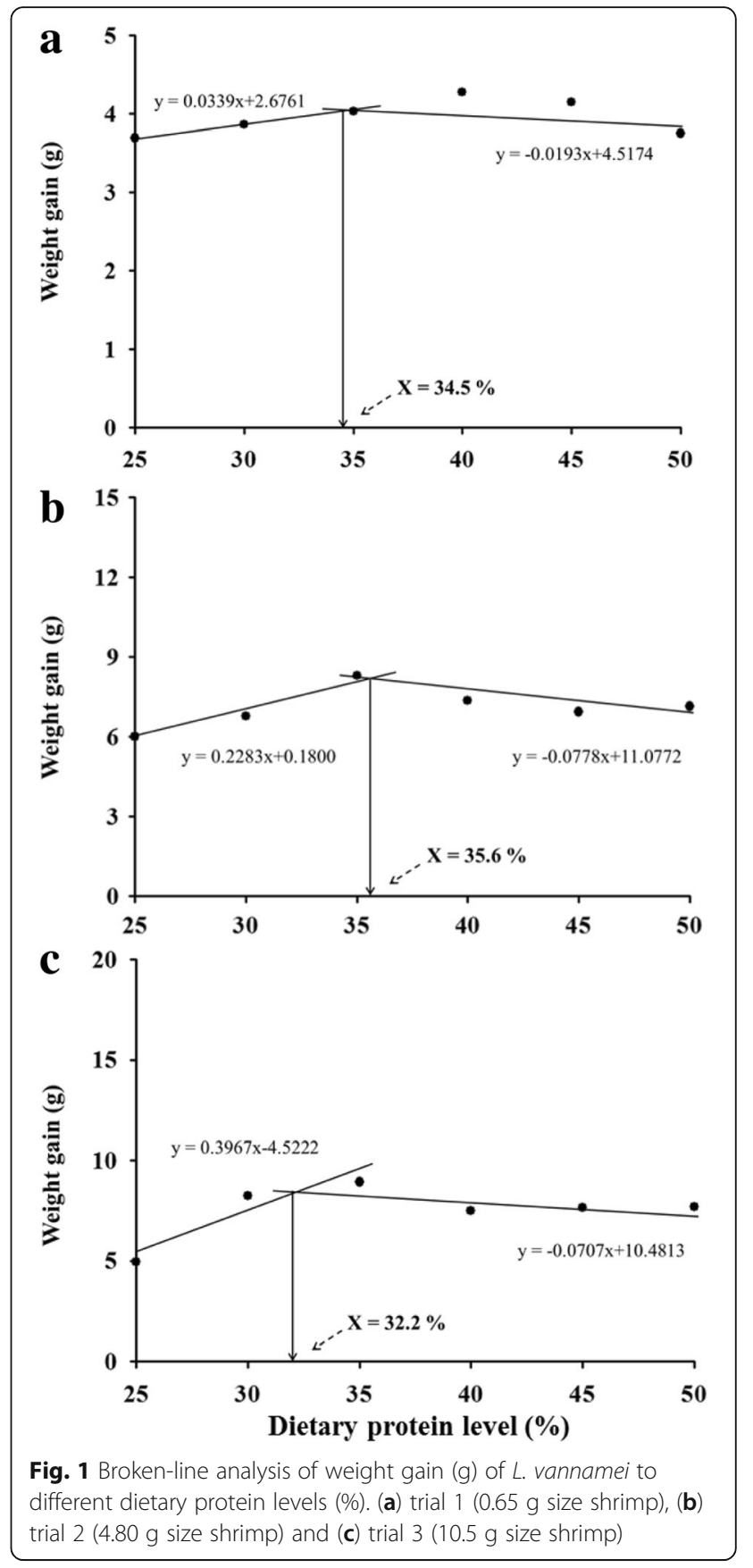

attractant and gelatin and casein as purified ingredients were used as the main protein sources. The semi-purified experimental diets were readily accepted by the shrimp during the whole feeding trials. The growth of the shrimp was equal to or better than that reported for similar-sized L. vannamei exposed to formulated diets in which no purified ingredients are used. Smith et al. (1985) conducted three feeding trials with similar-sized groups of $L$. vannamei and found $0.21,0.15$, and $0.10 \mathrm{~g}$ body increase per day for 4.0, 9.8, and 20.8 g sized groups, respectively. Rosas et al. (2001) reported daily body increase of 0.04 
Table 2 Growth performance and feed utilization of L. vannamei fed the six experimental diets containing six different levels of crude protein $(25,30,35,40,45$, and 50\% for P25, P30, P35, P40, P45, and P50, respectively)

\begin{tabular}{|c|c|c|c|c|c|c|}
\hline & \multicolumn{6}{|c|}{ Experimental diets } \\
\hline & $\mathrm{P} 25$ & P30 & P35 & P40 & P45 & P50 \\
\hline \multicolumn{7}{|c|}{ Trial 1 (initial BW 0.65 g) } \\
\hline $\mathrm{FBW}^{1}$ & $4.34 \pm 0.66$ & $4.46 \pm 0.38$ & $4.68 \pm 0.24$ & $4.92 \pm 0.66$ & $4.80 \pm 0.53$ & $4.40 \pm 0.28$ \\
\hline$W G^{2}$ & $571 \pm 103$ & $586 \pm 58.4$ & $619 \pm 36.3$ & $660 \pm 102$ & $637 \pm 86.8$ & $579 \pm 44.1$ \\
\hline$\left.\mathrm{DB}\right|^{3}$ & $0.10 \pm 0.02$ & $0.11 \pm 0.01$ & $0.11 \pm 0.01$ & $0.12 \pm 0.02$ & $0.12 \pm 0.01$ & $0.10 \pm 0.01$ \\
\hline$F C R^{4}$ & $1.77 \pm 0.36$ & $1.43 \pm 0.35$ & $1.32 \pm 0.23$ & $1.49 \pm 0.34$ & $1.58 \pm 0.19$ & $1.41 \pm 0.36$ \\
\hline $\mathrm{PER}^{5}$ & $2.33 \pm 0.45^{\mathrm{ab}}$ & $2.37 \pm 0.58^{a}$ & $2.16 \pm 0.40^{\mathrm{abc}}$ & $1.58 \pm 0.37^{\mathrm{bc}}$ & $1.42 \pm 0.18^{c}$ & $1.47 \pm 0.33^{b c}$ \\
\hline Survival ${ }^{6}$ & $88.9 \pm 7.86$ & $85.2 \pm 3.21$ & $85.2 \pm 3.21$ & $86.1 \pm 3.93$ & $92.6 \pm 32.1$ & $83.3 \pm 0.00$ \\
\hline \multicolumn{7}{|c|}{ Trial 2 (initial BW $4.81 \mathrm{~g}$ ) } \\
\hline $\mathrm{FBW}^{1}$ & $10.8 \pm 0.93^{b}$ & $11.6 \pm 0.43^{\mathrm{ab}}$ & $13.1 \pm 1.18^{\mathrm{a}}$ & $12.2 \pm 0.92^{\mathrm{ab}}$ & $11.7 \pm 0.15^{\mathrm{ab}}$ & $12.0 \pm 1.32^{\mathrm{ab}}$ \\
\hline$W G^{2}$ & $125 \pm 19.1^{b}$ & $141 \pm 8.43^{\mathrm{ab}}$ & $173 \pm 23.5^{\mathrm{a}}$ & $153 \pm 18.6^{\mathrm{ab}}$ & $145 \pm 3.94^{\mathrm{ab}}$ & $148 \pm 27.4^{\mathrm{ab}}$ \\
\hline$\left.\mathrm{DB}\right|^{3}$ & $0.14 \pm 0.02^{b}$ & $0.16 \pm 0.01^{\mathrm{ab}}$ & $0.20 \pm 0.03^{b}$ & $0.18 \pm 0.02^{\mathrm{ab}}$ & $0.17 \pm 0.00^{\mathrm{ab}}$ & $0.17 \pm 0.03^{\mathrm{ab}}$ \\
\hline $\mathrm{FCR}^{4}$ & $2.29 \pm 0.25^{\mathrm{a}}$ & $2.06 \pm 0.13^{\mathrm{ab}}$ & $1.71 \pm 0.29^{b}$ & $1.71 \pm 0.18^{b}$ & $2.01 \pm 0.27^{\mathrm{ab}}$ & $1.83 \pm 0.33^{\mathrm{ab}}$ \\
\hline $\mathrm{PER}^{5}$ & $1.70 \pm 0.19^{\mathrm{a}}$ & $1.60 \pm 0.10^{\mathrm{a}}$ & $1.67 \pm 0.31^{\mathrm{a}}$ & $1.47 \pm 0.16^{\mathrm{ab}}$ & $1.12 \pm 0.16^{b}$ & $1.12 \pm 0.18^{b}$ \\
\hline Survival $^{6}$ & $91.7 \pm 8.33$ & $88.9 \pm 12.7$ & $83.3 \pm 8.33$ & $80.6 \pm 4.81$ & $80.6 \pm 9.62$ & $86.1 \pm 12.7$ \\
\hline \multicolumn{7}{|c|}{ Trial 3 (initial BW 10.5 g) } \\
\hline $\mathrm{FBW}^{1}$ & $15.5 \pm 0.47^{b}$ & $18.7 \pm 0.77^{\mathrm{a}}$ & $19.5 \pm 2.02^{\mathrm{a}}$ & $18.0 \pm 0.26^{\mathrm{a}}$ & $18.2 \pm 0.73^{\mathrm{a}}$ & $18.3 \pm 1.05^{\mathrm{a}}$ \\
\hline$W G^{2}$ & $46.8 \pm 4.59^{b}$ & $77.8 \pm 6.88^{\mathrm{a}}$ & $85.2 \pm 19.4^{\mathrm{a}}$ & $70.9 \pm 2.95^{\mathrm{a}}$ & $72.8 \pm 6.62^{\mathrm{a}}$ & $72.9 \pm 10.4^{\mathrm{a}}$ \\
\hline$\left.\mathrm{DB}\right|^{3}$ & $0.10 \pm 0.01^{b}$ & $0.17 \pm 0.02^{\mathrm{a}}$ & $0.19 \pm 0.04^{\mathrm{a}}$ & $0.16 \pm 0.01^{\mathrm{a}}$ & $0.16 \pm 0.01^{\mathrm{a}}$ & $0.16 \pm 0.02^{\mathrm{a}}$ \\
\hline$F C R^{4}$ & $2.76 \pm 0.26^{\mathrm{a}}$ & $1.64 \pm 0.16^{b}$ & $1.55 \pm 0.32^{b}$ & $1.72 \pm 0.14^{b}$ & $1.69 \pm 0.22^{b}$ & $1.80 \pm 0.29^{b}$ \\
\hline $\mathrm{PER}^{5}$ & $1.38 \pm 0.13^{c}$ & $1.98 \pm 0.19^{\mathrm{a}}$ & $1.88 \pm 0.41^{\mathrm{ab}}$ & $1.49 \pm 0.12^{\mathrm{bc}}$ & $1.33 \pm 0.17^{c}$ & $1.15 \pm 0.18^{c}$ \\
\hline Survival ${ }^{6}$ & $87.9 \pm 10.5$ & $97.0 \pm 5.25$ & $90.9 \pm 0.00$ & $81.8 \pm 15.7$ & $81.8 \pm 0.00$ & $81.8 \pm 9.09$ \\
\hline
\end{tabular}

Values are mean of triplicate groups and presented as mean \pm S.D. Values with different superscript letters in the same row are significantly different $(P<0.05)$.

The lack of superscript letter indicates no significant differences among treatments

${ }^{1} \mathrm{FBW}$ final body weight (g)

${ }^{2}$ Weight gain $(\%)=[($ final mean body weight - initial mean body weight $) /$ initial mean body weight $] \times 100$

${ }^{3}$ Daily body increase $(\mathrm{g} /$ day $)=($ final body weight - initial body weight $) /$ days

${ }^{4}$ Feed conversion ratio $=$ dry feed fed $(\mathrm{g}) /$ wet weight gain $(\mathrm{g})$

${ }^{5}$ Protein efficiency ratio $=$ wet weight gain/total protein given

${ }^{6}$ Survival (\%)

Table 3 Whole-body composition of L. vannamei fed the six experimental diets containing six different levels of crude protein $(25,30,35,40,45$, and $50 \%$ for P25, P30, P35, P40, P45, and P50, respectively)

\begin{tabular}{|c|c|c|c|c|c|c|}
\hline & \multicolumn{6}{|c|}{ Experimental diets } \\
\hline & P25 & P30 & P35 & P40 & P45 & P50 \\
\hline \multicolumn{7}{|c|}{ Trial 1 (initial BW 0.65 g) } \\
\hline Moisture & $83.6 \pm 3.12^{\mathrm{a}}$ & $76.3 \pm 2.73^{c}$ & $77.6 \pm 1.17^{\mathrm{bc}}$ & $76.5 \pm 1.61^{c}$ & $77.4 \pm 0.78^{\mathrm{bc}}$ & $79.1 \pm 0.45^{b}$ \\
\hline Protein & $76.6 \pm 4.78$ & $76.8 \pm 5.47$ & $80.9 \pm 5.13$ & $78.3 \pm 6.69$ & $76.6 \pm 3.91$ & $79.3 \pm 2.04$ \\
\hline Lipid & $5.15 \pm 0.95$ & $4.87 \pm 0.88$ & $4.57 \pm 0.08$ & $4.22 \pm 0.65$ & $4.93 \pm 0.75$ & $5.42 \pm 0.97$ \\
\hline Ash & $21.0 \pm 2.46$ & $20.2 \pm 1.66$ & $20.2 \pm 1.67$ & $20.9 \pm 1.26$ & $20.7 \pm 0.93$ & $20.5 \pm 1.05$ \\
\hline \multicolumn{7}{|c|}{ Trial 3 (initial BW 10.5 g) } \\
\hline Moisture & $76.5 \pm 1.13^{\mathrm{a}}$ & $74.6 \pm 1.47^{\mathrm{bc}}$ & $75.6 \pm 1.08^{\mathrm{ab}}$ & $74.5 \pm 0.24^{\mathrm{bc}}$ & $73.4 \pm 1.35^{c}$ & $76.2 \pm 0.55^{\mathrm{a}}$ \\
\hline Protein & $75.6 \pm 3.63^{b}$ & $82.8 \pm 1.60^{a}$ & $82.7 \pm 1.93^{\mathrm{a}}$ & $82.9 \pm 2.54^{\mathrm{a}}$ & $84.1 \pm 0.92^{a}$ & $83.7 \pm 2.04^{a}$ \\
\hline Lipid & $4.45 \pm 0.34$ & $4.67 \pm 0.31$ & $4.64 \pm 0.47$ & $4.57 \pm 0.34$ & $4.70 \pm 0.15$ & $4.57 \pm 0.31$ \\
\hline Ash & $13.0 \pm 1.32$ & $12.3 \pm 1.14$ & $13.1 \pm 1.20$ & $12.6 \pm 0.68$ & $12.6 \pm 0.68$ & $13.7 \pm 0.95$ \\
\hline
\end{tabular}

Values are mean of triplicate groups and presented as mean \pm S.D. Values with different superscript letters in the same row are significantly different $(P<0.05)$. 
and $0.13 \mathrm{~g}$ for 0.3 and $1.5 \mathrm{~g}$ sized groups of L. vanna$m e i$, respectively. Xia et al. (2010) also reported a daily body increase of approximately $0.10 \mathrm{~g}$ in $6.2 \mathrm{~g}$ sized $L$. vannamei. These previous studies (Smith et al. 1985; Rosas et al. 2001; Xia et al. 2010) had used all practical diets for the feeding trials. In the present study, higher growth was observed as calculated as daily body increase of $0.11,0.17$, and 0.15 for $0.65,4.81$, and $10.5 \mathrm{~g}$ sized groups of L. vannamei, although semi-purified diets were used. Therefore, the semi-purified diet in the present study seems to be formulated nutritionally well balanced to support optimal growth of juvenile, sub-adult, and adult sized of L. vannamei.

Generally, practical experimental diets have been used in most protein requirement studies for Penaeid shrimps. Most previous studies had used practical ingredients, i.e., fish meal and soybean meal as the main protein sources to increase or decrease the crude protein levels in the practical experimental diets. When fish meal is used as the main protein source to gradually increase the crude protein in diets for protein requirement study (Xia et al. 2010; Yun et al. 2016), the result might be over-estimated because of unknown growth factors in fish meal. On the other hand, when soybean meal (Kureshy and Davis 2002) is used as the main protein source, the result might be under-estimated because of its anti-nutritional factors. In this regard, the present result could be very significant in providing protein requirement data for Penaeid shrimp by using semi-purified experimental diets.

The recommended dietary protein levels from previous studies vary from 30 to $57 \%$ for Penaeid shrimps. The present study showed that the difference in protein levels affected the growth and feed utilization of L. vannamei (Table 2). A broken line analysis based on weight gain suggested that the optimal dietary protein levels would be 34.5 and $35.6 \%$ for small-sized (0.6-5 g) and medium-sized (4-13 g) groups of $L$. vannamei. The optimum dietary protein level for maximum growth of L. vannamei can be affected by differences in shrimp size, stocking density, species of shrimp, culture system, and dietary protein sources. In the range of approximately $1 \mathrm{~g}$ sized shrimp, optimal growth was observed with 33 to $44 \%$ crude protein in diets when krill meal was used as a main protein source (Rosas et al. 2001). Gao et al. (2016) reported that the optimum dietary protein level for L. vannamei (0.31-6.0 g size) was $34 \%$ when a semi-purified diet was used. Shahkar et al. (2014) reported that $33 \%$ dietary protein level is optimum for an optimal growth of L. vannamei (approximately $1-11 \mathrm{~g}$ size) when fish meal was used as the main protein source, whereas Martinez-cordova et al. (2003) found that the optimal protein level was $25 \%$ when L. vannamei (1-17 g size) was cultured in a pond system with three commercial diets containing 25, 35, and $40 \%$ CP for 16 weeks. In a very high salinity condition $(60 \mathrm{~g} / \mathrm{L})$, the optimum dietary protein level was estimated to $46.7 \%$ when the L. vannamei (0.09-2.2 g size) was fed a semi-purified diet (Sui et al. 2015).

Most of the protein requirement studies on shrimp are limited to the juvenile stages, and the protein requirements of post-juvenile stages have mostly been estimated. There has been little information about the protein requirement during the adult stage of the shrimp. Based on the growth of large shrimp (10-20 g size) in the present study, the optimal dietary protein level was estimated to be $32.2 \%$ by a broken line analysis. To the best of our knowledge, one study (Smith et al. $1985)$ is available with which to compare the growth of large (10-20 g size) L. vannamei in the present study. Smith et al. (1985) reported that adult-sized (20-25 g) shrimp was not affected by the protein levels but affected by protein sources (animal or plant), whereas small-sized shrimp (4-11 g) was significantly affected by protein levels. The difference in results between the present study and Smith et al. (1985) can be explained mainly by the difference in protein sources such as semi-purified sources (casein and gelatin) and practical sources (shrimp meal), respectively, as well as different experimental conditions.

The PER tended to decrease with increased dietary protein, which is consistent with results in shrimp $(\mathrm{Hu}$ et al. 2008; Xia et al. 2010; Shahkar et al. 2014). The lowest PER found in 40 to $50 \%$ protein diets indicates that the excessive protein was used for metabolic purposes other than growth. Usually, a low dietary protein is efficiently utilized for protein synthesis by shrimp (Shiau and Peng 1992; Hu et al. 2008; Xia et al. 2010). Also, the differences in protein sources could result in different PER values (Hajra et al. 1988). In the present study, fish meal was fixed to $18 \%$ and then casein and gelatin mix $(4: 1, v / v)$ was gradually increased to make the dietary protein level different. Therefore, the differences in PER values in the present study might be attributed to the difference only in protein level rather than protein quality.

The differences in the quantity or quality of protein, the ratio of dietary protein to energy, and species contribute to the varying effects of dietary protein on carcass composition (Hubbard et al. 1986; Siccardi, 2006). The lower whole-body protein content was observed in low level of dietary protein (P25 diet) which was often reported in fish species (Kim and Lee 2009; Shahkar et al. 2014). Also, Siccardi (2006) evaluated the requirement of daily digestible protein (DP) and digestible energy (DE) of L. vannamei with two types of diets (25\% CP diet and 35\% CP diet) and different feeding regimes. They concluded that the protein requirement of shrimp needs to be reevaluated considering feeding methods such as ad libitum/restricted 
feeding and daily feeding amount as well as dietary energy contents.

\section{Conclusion}

In conclusion, the broken line analysis of growth rate suggests that the optimum dietary crude protein level could be 34.5 , 35.6, and $32.2 \%$ for L. vannamei in three different growth stages (small-, medium-, and large-sized shrimp, respectively).

\section{Abbreviations}

ANOVA: Analysis of variance; FBW: Final body weight; FCR: Feed conversion ratio; PER: Protein efficiency ratio

\section{Acknowledgements}

This work has supported by the National Research Foundation of Korea (NRF) grant funded by the Korea government (MSIT) (NRF-

2015R1A2A2A01004366)

\section{Availability of data and materials}

All datasets analyzed during the current study are available from the corresponding author on reasonable request.

\section{Authors' contributions}

$\mathrm{CL}$ manufactured the experimental diet, conducted the feeding trial and analysis, and drafted the manuscript. KJL designed this study, led in analyzing data derived from this study, and revised the manuscript. Both authors read and approved the final manuscript.

\section{Ethics approval and consent to participate}

Experimental protocols followed the guidelines of the Animal Care and Use Committee of Jeju National University.

\section{Consent for publication}

Not applicable.

\section{Competing interests}

The authors declare that they have no competing interests.

\section{Publisher's Note}

Springer Nature remains neutral with regard to jurisdictional claims in published maps and institutional affiliations.

Received: 15 May 2018 Accepted: 12 July 2018

Published online: 03 October 2018

\section{References}

AOAC (Association of Official Analytical Chemists). Official methods of analysis. $18^{\text {th }}$ edition. Washington, DC: Association of Official Analytical Chemists; 2005.

Folch J, Lees M, Sloane-Stanley GH. A simple method for the isolation and purification of total lipids from animal tissues. J boil Chem. 1957;226:497-509.

Gao W, Tian L, Hu W, Luo M, Liu J, Xu Q, et al. Optimal dietary protein level for the white shrimp (Litopenaeus vannamei) in low salinity water. Isr J AquacultBamid. 2016:68:1320.

Hajra A, Ghosh A, Mandal SK. Biochemical studies on the determination of optimum dietary protein to energy ratio for tiger prawn, Penaeus monodon (Fab.), juveniles. Aquaculture. 1988;71:71-9.

Hu Y, Tan B, Mai K, Ai Q, Zheng S, Cheng K. Growth and body composition of juvenile white shrimp, Litopenaeus vannamei, fed different ratios of dietary protein to energy. Aquac Nutr. 2008;14:499-506.

Hubbard DM, Robinson EH, Brown PB, Daniels WH. Optimum ratio of dietary protein to energy for red crayfish (Procambarus clarkii). Prog Fish Cult. 1986; 48:233-7.

Jatobá A, da Silva BC, da Silva JS, do Nascimento Vieira F, Mouriño JLP, Seiffert $W Q$, et al. Protein levels for Litopenaeus vannamei in semi-intensive and biofloc systems. Aquaculture. 2014;432:365-71.
Kim KI, Kayes TB, Amundson CH. Purified diet development and re-evaluation of the dietary protein requirement of fingerling rainbow trout (Oncorhynchus mykiss). Aquaculture. 1991;96:57-67.

Kim SS, Lee KJ. Dietary protein requirement of juvenile tiger puffer (Takifugu rubripes). Aquaculture. 2009;287:219-22.

Kureshy N, Davis DA. Protein requirement for maintenance and maximum weight gain for the Pacific white shrimp, Litopenaeus vannamei. Aquaculture. 2002;204:125-43.

Martinez-Cordova LR, Campana Torres A, Porchas-Cornejo MA. Dietary protein level and natural food management in the culture of blue (Litopenaeus stylirostris) and white shrimp (Litopenaeus vannamei) in microcosms. Aquac Nutr. 2003;9:155-60.

National Research Council. Nutrient requirements of fish and shrimp. Washington, DC: National Academies Press; 2011

Perez-Velazquez M, González-Félix ML, Jaimes-Bustamente F, Martínez-Córdova $L R$, Trujillo-Villalba DA, et al. Investigation of the effects of salinity and dietary protein level on growth and survival of Pacific white shrimp, Litopenaeus vannamei. J World Aquac Soc. 2007;38:475-85.

Rosas C, Cuzon G, Taboada G, Pascual C, Gaxiola G, Van Wormhoudt A. Effect of dietary protein and energy levels on growth, oxygen consumption, haemolymph and digestive gland carbohydrates, nitrogen excretion and osmotic pressure of Litopenaeus vannamei (Boone) and L. setiferus (Linne) juveniles (Crustacea, Decapoda; Penaeidae). Aquac Res. 2001;32:531-47.

Shahkar E, Yun H, Park G, Jang IK, Kim SK, Katya K, et al. Evaluation of optimum dietary protein level for juvenile whiteleg shrimp (Litopenaeus vannamei). J Crustacean Biol. 2014:34:552-8.

Shiau SY, Peng CY. Utilization of different carbohydrates at different dietary protein levels in grass prawn, Penaeus monodon, reared in seawater. Aquaculture. 1992;101:241-50.

Siccardi AJ. Daily digestible protein and energy requirement for growth and maintenance of sub-adult pacific white shrimp (Litopenaeus vannamei). PhD dissertation. College Station: Texas A\&M University; 2006.

Smith LL, Lee PG, Lawrence AL, Strawn K. Growth and digestibility by three sizes of Penaeus vannamei Boone: effects of dietary protein level and protein source. Aquaculture. 1985;46:85-96.

Sui L, Ma G, Deng Y. Effect of dietary protein level and salinity on growth, survival, enzymatic activities and amino-acid composition of the white shrimp Litopenaeus vannamei (Boone, 1931) juveniles. Crustaceana. 2015;88 82-95.

Velasco M, Lawrence AL, Castille FL, Obaldo LG. Dietary protein requirement for Litopenaeus vannamei. Avances en Nutrición Acuícola V. Memorias del V Simposium Internacional de Nutrición Acuícola. Mexico;2000:19-22.

Venero JA, Davis DA, Rouse DB. Effect of the dietary ratio of digestible energy to crude protein on growth and feed conversion in juvenile pacific white shrimp Litopenaeus vannamei under similar levels of daily protein consumption. N Am J Aquac. 2008:70:43-9.

Wilson RP. Amino acids and proteins, In: Halver, J.E., Hardy, R.W. (Eds.), Fish nutrition, 3 rd ed. Academic Press. San Diego:2002. 144-175.

Xia S, Li Y, Wang W, Rajkumar M, Vasagam K, Paramasivam K, et al. Influence of dietary protein levels on growth, digestibility, digestive enzyme activity and stress tolerance in white-leg shrimp, Litopenaeus vannamei (Boone, 1931), reared in high-density tank trials. Aquac Res. 2010;41:1845-54.

Yun H, Lee J, Park G, Jang IK, Katya K, Shahkar E, et al. Reevaluation of optimum dietary protein level in juvenile whiteleg shrimp, Litopenaeus vannamei (Boone, 1931). Anim Nutr Feed Techn. 2015;15:385-94.

Yun H, Shahkar E, Katya K, Jang IK, Bai SC. Effects of bioflocs on dietary protein requirement in juvenile whiteleg shrimp, Litopenaeus vannamei. Aquac Res. 2016;47:3203-14

Zhou JB, Zhou QC, Chi SY, Yang QH, Liu CW. Optimal dietary protein requirement for juvenile ivory shell, Babylonia areolate. Aquaculture. 2007;270: $186-92$ 